Board will welcome any help you can give us in securing well written articles on these and other topics.

\title{
General
}

Regarding the mechanics of production it is a pleasure to report that our publication is in a healthy state. There is a small backlog of articles, the articles for the December issue are at the printers, and all concerned are co-operating fully.

Because there will be no Proceedings for this joint meeting, articles will be published in the journal of the Society of the country in which the author resides. This is providing, of course, that the articles are approved by the appropriate review boards. Incidentally I want to congratulate the Quebec Section and the Corporation of Forest Engineers of Quebec for doing such a fine job of publishing the Proceedings of the Annual Meeting at Quebec for distribution to all members of the C.I.F. It is a pleasure to report that all C.I.F. members attending the Minneapolis meeting will receive a free copy of the December issue of the Journal of Forestry which will carry the major speeches and will report highlights of the joint meeting. Our Annual Meeting papers will be published in the March issue of The Forestry Chronicle. Extra copies may be ordered in advance from Jim Dosne at $\$ 2.00$ each.

Acknowledgements

In conclusion I want to thank Jim Dosne for help throughout the year, the Executive Committee for support and guidance, the Editorial Board for constructive reviews and sharing of my burdens as Editor, Section News Representatives for faithful and interesting reporting, and Walter Giles, Cam Place, George Sinclair, and Jim Collins for providing useful services to our readers. Alex Donaldson and Mitchell Press have done a fine job for us. We must also thank our fellow foresters who have strived to improve the science and practice of forestry by submitting articles for publication. Writing is a difficult task that has few tangible rewards. We should offer our personal thanks to all who have contributed and hope that their fine example will inspire more and even better articles, especially on professional forestry topics.

J. H. G. SMITH

\section{Minutes of the 53rd Annual Meeting of Members MiNNEAPOLIS, MiNN.}

October 9th, 1961 - 1:30 p.m. to 4:30 p.m.

The meeting was called to order at $1.30 \mathrm{pm}$. President L. Besley was in the Chair. There were about 200 members present.

1. Adoption of the minutes of the $\mathbf{1 9 6 0}$ Annual Meeting Motion (16:61) 1 1) K. W. Hearnden 2) J. M. Kinghorn (15 motions were passed at the Board of Directors' Meeting)

2. Period of Silence

In respect to the memory of members deceased during the year, one minute of silence was observed. 

L. P. L'Ecuyer
W. W. Stevens
-Quebec City
A. W. Raminsh
-Kamloops, B.C.
W. B. Greenwood
- Cochrane, Ont.
W. L Bubie
T. Elliott
-Toronto, Ont.
Dr. H. T. Gussow
-Shawinigan, Que.
-Monte Lake, B.C.
- Victoria, B.C.

\section{Report of the Immediate Past President}

The report is published in the December issue of The Forestry Chronicle.

\section{Report of the Secretary Manager}

The report is published in the December issue of The Forestry Chronicle. It was approved on a

Motion (17:61) 1) Dean J. W. B. Sisam 2) Dr. R. W. Wellwood

\section{Report of the Editor}

The report is published in the December issue of The Forestry Chronicle. It was approved on a

Motion (18:61) 1) K. A. Armson 2) F. Matte

\section{Highlights of the Board of Directors' Meeting}

1) Sixteen of the 20 sections were represented this year.

2) The Co-Chairman of this Joint Annual Meeting, Mr. George Sonley, presented a most interesting and useful report which contained a number of specific suggestions for planning and managing future Annual Meetings. The Board specifically requested that this splendid report be filed with the Secretary Manager and be made available both to host sections planning future meetings and to future Executive Committees involved in planning with the Secretary Manager his activities and in recommending future budgets.

3) The President announced that the following had been appointed to the Resolutions Committee: D. R. Cameron, Chairman (B.C.), D. A. Wilson (Que.) and E. S. Fellows (N.B.). This Committee was confirmed. 4) Following the immediate Past-President's report all the general actions of the Executive Committee for the year wre approved. Four major matters were discussed in detail, and were acted upon individually.

a) The Chairman of the Re-location of Head Office Committee reported on the work of his Committee. The propriety of the relocation of our Office without the prior approval of the Board was questioned by several Directors and the Executive Committee expressed its regret that the Directors had not been officially polled by mail or telegram before final decision. However, after discussion, the action of the Committee was approved by the Board.

It was agreed that the Executive Committee should appoint a Committee to proceed with a study of the ultimate possibility of construction of a permanent building. This Committee is to report to the Board within three years.

b) The 1961-62 budget recommended by the Executive Committee provided a $\$ 1,000$ deficit to be taken from surplus. This proposed 
deficit was raised to $\$ 1,500$ to provide a contingency fund of $\$ 500$. The immediate purpose of this increase is to pay for the non-recoverable expenses incurred by the North-western Ontario Section in connection with the Join Annual Meeting.

c) The increase in dues, effective in the 1962-63 fiscal year, as recommended by the Executive Committee was discussed in detail with every Section Representative presenting his Section's views. The proposed increase was approved by a vote of 12 to 6 .

d) It was the concensus of the Directors that a project worth of study and report by the Sections for the ensuing year should be a definition of a policy and specific program for our Institute. The Committee on Economics and Policy will submit a tentative policy and program early next year and this will be forwarded to every section for a thorough study and detailed recommendations to be sent to the Committee for incorporation in a final draft to be submitted to the Board of Directors and the Annual Meeting in Vancouver for action.

5) The question of better communication from Head office to the Membership was discussed at length. It was agreed that among our members, there is a widespread lack of knowledge and of an appreciation of the functions and activities of the Institute. Problems involved in providing dues receipts, estimating budget requirements, and the work of the Executive Committee should be more fully appreciated. More information should be supplied to all members both through their Section officers and through The Forestry Chronicle. Also, the need for better communication from members and their Sections to the National Office, was discussed. It is a two-way street and more satisfaction can be attained from mutual cooperation.

6) The policy governing the publication and contents of The Forestry Chronicle and the Supplement came under extensive discussion. General satisfaction with the publication in its present form was expressedbut it was acknowledged that it is not yet fulfilling what should be one of its prime functions, the unification of the profession on a national level. It was agreed that in the interests of economy there should be a reduction in the advertising sales campaign because it has been revealed that the returns from this source of revenue are not commensurate with the time required of our Secretary Manager and the direct costs involved.

Comments and criticisms were most constructive and the Directors voted unanimously their warm thanks to the Editor for a job performed most competently with only nominal and far too little remuneration. 7) Mr. Hodgins reported that the C.I.F. Recommendations to the Minister of Forestry were acknowledged and the 32 points (as published in the Sept. 61 Chronicle) were dealt with in detail by the Minister. The Minister's letter will be circulated to all Sections.

8) Brief reports of some of the National Committees were presented to the Board. The President pointed out that the 3 year terms of the 
members of several Standing Committees expired this year and asked that suggestions of new members for these Committees should be made to him not later than November 8th, 1961. These Committees are: By-Laws, Forest Economics and Policy, Silviculture, Forest Management, Forestry Correspondence Course, and Wildlife. Present membership is listed in the March Supplement.

9) Mr. H. J. Hodgins was elected third member of the C.I.F. Executive Committee to serve along with the President and the Vice-President.

10) It was agreed by the Directors that an extensive revision of the Institute By-Laws is urgently needed in order that these may provide for what is now established as acceptable and effective working procedures. This revision will be based upon a through study and recommendation to be made to the Board by a newly formed By-Laws Committee.

11) By unanimous vote, the Board of Directors nominated for Honorary Member, W. W. McCormick, Deputy Minister of Lands and Forests for New Brunswick (Retired).

12) Tentative invitations to host national meetings in 1964,1965 or 1966 and other years, were gratefully received by the Board from the Saguenay Section, Newfoundland Section, Manitoba Section and the Rocky Mountain Section. The President was instructed to invite the SAF to hold a joint C.I.F. - S.A.F. Meeting in Ottawa in 1967.

13) A Committee was to be appointed to investigate the suggestions of a C.I.F. Ring for all Forestry graduates in Canada.

14) A Vote of thanks was given to the immediate Past-President.

The above actions of the Board of Directors were approved on Motion (19:61) by 1) R. A. Cameron 2) Dean J. W. B. Sisam

\section{Re-location of Head Office}

Mr. W. A. E. Pepler, Chairman of the Relocation Committee reported on the work of his Committee. The action of the Executive Committee on the relocation without the prior approval of the Board was discussed at length. It was agreed that the office remain at Macdonald College and that the Executive Committee appoint a committee to proceed with a study of the ultimate possibility of construction of a permanent building. This committee to report to the Board of Directors within 3 years.

Motion (20:61) 1) Dr. G. W. I. Creighton 2) R. S. M. Bunney

\section{Increase of Dues for 1962-63}

It was agreed to approve the increase of dues, effective in the fiscal year 1962-63, as approved by the Board of Directors (covered in Motion 19:61 above).

The dues will be as follows:

Classes of Membership

1961-62

Dues

Active members 13.00

1962-63

(over 3 years since graduation)

Active members

10.00

15.00

12.00 